\title{
SPOŁECZNA ODPOWIEDZIALNOŚĆ BIZNESU FIRM LOGISTYCZNYCH
}

\begin{abstract}
W artykule poddano analizie rolę i znaczenie społecznej odpowiedzialności biznesu (CSR) dla współczesnych przedsiębiorstw na przykładzie firm logistycznych. Rozważania skoncentrowano na istocie i zakresie społecznej odpowiedzialności biznesu oraz metodach realizacji w przedsiębiorstwach logistycznych zasad zrównoważonego rozwoju, a zwłaszcza zasad zielonej logistyki i społecznej odpowiedzialności biznesu w sferze relacji $\mathrm{z}$ otoczeniem społecznym.
\end{abstract}

CSR to koncepcja, w której przedsiębiorstwa dobrowolnie decydują się wspierać działania na rzecz lepszego społeczeństwa i czystszego środowiska. Rozumiana jest także jako ciagłe zobowiązanie biznesu do zachowywania się w sposób etyczny oraz wspierania rozwoju ekonomicznego poprzez polepszanie jakości życia pracowników, ich rodzin, jak i społeczności lokalnych oraz całych społeczeństw. Realizacja jej zasad przyczynia się do osiaggania zrównoważonego rozwoju globalnego. Praktycy i teoretycy biznesu poszukują możliwości wykorzystania zasad społecznej odpowiedzialności biznesu w logistyce.

Zaangażowanie CSR w branży logistycznej może wynikać z trzech powodów. Po pierwsze z szerokiego kontekstu gospodarczego. Współczesna gospodarka ma charakter globalny, pod każdym względem, a przedsiębiorstwa, aby mogły się rozwijać muszą być aktywne w prowadzeniu działalności gospodarczej wśród grup dostawców i klientów. Po drugie logistyka zajmuje strategiczną pozycję pomiędzy innymi sektorami, co daje jej ogromną różnorodność przedsiębiorstw i sektorów przemysłu. Po trzecie firmy logistyczne znajdują się pod ciągła presją klientów i społeczeństwa, aby odpowiedzialność społeczna była trwałym składnikiem ich strategii, co wydaje się uzasadnione biorąc pod uwagę silną konkurencję na rynku.

Praktyka pokazuje, że społecznie odpowiedzialna logistyka polega na wdrażaniu narzędzi oceny dostawców pod kątem spełniania przez nich kryteriów społecznych i środowiskowych, implementowaniu kodeksów etycznych i postępowania, procedur działania oraz zintegrowanych programów opartych na ciagłym doskonaleniu.

Słowa kluczowe: społeczna odpowiedzialność biznesu, firmy logistyczne, społecznie odpowiedzialna logistyka, zrównoważony rozwój, zielona logistyka

\section{WPROWADZENIE}

Globalizacja rynków i towarzyszący jej szybki rozwój różnego rodzaju mediów przyspieszających przepływ informacji przyczyniają się do wzrostu udziału biznesu w życiu społecznym oraz wzrostu bezpośredniego wpływu podmiotów gospodarczych na

\footnotetext{
${ }^{1}$ Dr Adam Laska, Zakład Nauk Humanistycznych, Wydział Zarządzania, Politechnika Rzeszowska, ul. Powstańców Warszawy 8, 35-959 Rzeszów, tel. 01786539 59, autor korespondencyjny e-mail: alaska@prz.edu.pl

2 Dr inż. Renata Piętowska-Laska, Katedra Systemów Zarządzania i Logistyki, Wydział Zarządzania, Politechnika Rzeszowska, ul. Powstańców Warszawy 8, 35-959 Rzeszów, tel. 017865 1804
} 
kształt społeczeństwa ${ }^{3}$. Społeczna odpowiedzialność biznesu (CSR, corporate social responsibility) to „koncepcja, w której przedsiębiorstwa dobrowolnie decydują się wspierać działania na rzecz lepszego społeczeństwa i czystszego środowiska. Jest procesem, który umożliwia zarządzanie relacjami z różnorodnymi grupami interesariuszy mającymi wpływ na funkcjonowanie przedsiębiorstwa”. Rozumiana jest także jako „ciągłe zobowiązanie biznesu do zachowywania się w sposób etyczny oraz wspierania rozwoju ekonomicznego poprzez polepszanie jakości życia pracowników, ich rodzin, jak i społeczności lokalnych oraz całych społeczeństw"4. Realizacja jej zasad przyczynia się do osiągania zrównoważonego rozwoju globalnego. Jednym z podnoszonych tematów dotyczących rozwoju CSR jest jej rola w logistyce (łańcuchach dostaw). Praktycy i teoretycy biznesu poszukują możliwości wykorzystania zasad społecznej odpowiedzialności biznesu do zarządzania łańcuchem dostaw i budowania trwałego oraz opartego na obustronnych korzyściach partnerstwa. Wynikiem podjętych dyskusji są koncepcje, traktujące o problematyce odpowiedzialnego łańcucha dostaw, takie jak ${ }^{5}$ społecznie odpowiedzialna logistyka (LSR, logistics social responsibility) czy społecznie odpowiedzialne zakupy (PSR, purchasing social responsibility) ${ }^{6}$.

Mimo dużego wkładu w rozwój gospodarczy, początkowo logistyka nie cieszyła się dużym poważaniem. Dopiero od blisko pięćdziesięciu lat można mówić o logistyce jako jednym z ważniejszych wyznaczników wydajności przedsiębiorstw. W tym okresie działania logistyczne zostały tak skonstruowane, aby zmaksymalizować rentowność wszystkich firm w łańcuchu dostaw. Takie podejście do kalkulacji rentowności uwzględnia jedynie koszty ekonomiczne, ignorując koszty społeczne i środowiskowe wynikłe z działalności logistycznej.

Sytuacja uległa zmianie wraz $\mathrm{z}$ rozwojem społecznego zainteresowania minimalizowaniem negatywnego wpływu działań gospodarczych na szeroko rozumiane środowisko człowieka. Wraz z pojawieniem się koncepcji zrównoważonego rozwoju również branża logistyczna musiała podjąć działania zmierzające do wzrostu troski o środowisko przyrodnicze i społeczne, tak aby mogła zaspokajać wszystkie potrzeby interesariuszy ${ }^{7}$. Dodatkowym czynnikiem skłaniającym firmy logistyczne do ciagłego doskonalenia $\mathrm{w}$ relacjach $\mathrm{z}$ otoczeniem są działania podejmowane przez instytucje międzynarodowe i krajowe zmierzające do wprowadzenia i respektowania coraz wyższych standardów w działalności logistycznej.

Współcześnie przed branżą logistyczną pojawiło się zatem wiele wyzwań związanych z koniecznością udzielenia odpowiedzi na pytanie dotyczące postrzegania obowiązków społecznych przez firmy, a zwłaszcza ich wpływu na środowisko.

\footnotetext{
${ }^{3}$ G. Karwacka, Koncepcja społecznej odpowiedzialności w logistyce, http://www.innowrota.pl/sites/default/files/images/G.Karwacka_2.pdf (dostęp: 15.09.2014).

${ }^{4}$ World Business Council for Sustainable Development, Corporate Social Responsibility: Meeting Changing Expectations, Geneva 1999, s. 6; World Business Council for Sustainable Development, Corporate Social Responsibility: Making Good Business Sense, Geneva 2000, s. 7.

${ }^{5}$ M.J. Maloni, M.E. Brown, Corporate Social Responsibility in the Supply Chain: An Application in the Food Industry, ,Journal of Business Ethics” 2006/68, s. 36.

${ }^{6}$ A. Rudnicka, Odpowiedzialność społeczna $w$ globalnych tańcuchach dostaw na przyktadzie certyfikacji FairTrade, „Acta Universitatis Lodziensis, Folia Oeconomica” 2011/258, s. 163-164.

${ }^{7}$ Szerzej: M. Złoch, Największe wyzwanie to ochrona środowiska, Raport - Odpowiedzialność logistycznego biznesu, „Logistyka a Jakość” marzec-kwiecień 2011, s. 24-25.
} 


\section{POJECCIE I ZAKRES SPOŁECZNEJ ODPOWIEDZIALNOŚCI BIZNESU}

Społeczna odpowiedzialność biznesu to podejście strategiczne i długofalowe, oparte na zasadach dialogu społecznego i poszukiwaniu rozwiązań korzystnych dla wszystkich. $\mathrm{U}$ podstaw tych zasad leży koncepcja firmy zorientowanej na interesariuszy. „Interesariusze” to jedno z ważniejszych pojęć, które weszło do słownika biznesowego wraz ze społeczną odpowiedzialnością biznesu. Interesariusze (stakeholders) - określani również jako strony zainteresowane - to grupy lub jednostki, które mogą wpływać bądź są pod wpływem działania przedsiębiorstwa za pośrednictwem jego produktów, strategii i procesów wytwórczych, systemów zarządzania i procedur. Można zatem przyjąć, że interesariuszami firmy są w zasadzie wszyscy, ponieważ w globalnym świecie sieć wzajemnych powiązań jest coraz mocniejsza. Jednak z punktu widzenia danej firmy istotne są te relacje $\mathrm{z}$ interesariuszami, którymi można zarządzać.

Mówiąc o zakresie społecznej odpowiedzialności biznesu, na ogół wskazuje się na jego dwa podstawowe wymiary $^{8}$ : wewnętrzny i zewnętrzny. Wymiar wewnętrzny społecznej odpowiedzialności biznesu odnosi się do takich sfer jak:

- $\quad$ zarządzanie zasobami ludzkimi;

- zdrowie i bezpieczeństwo pracowników;

- elastyczność funkcjonowania;

- ochrona środowiska naturalnego;

- programy etyczne dla pracowników;

- nadzór korporacyjny.

- Wymiar zewnętrzny społecznej odpowiedzialności biznesu to działania skierowane na:

- prawa człowieka;

- globalne problemy ekologiczne;

- $\quad$ społeczności lokalne;

- partnerów handlowych, dostawców i klientów.

W Europie debata dotycząca społecznej odpowiedzialności biznesu została zainicjowana na Trzecim Europejskim Sympozjum Zarządzania, które odbyło się w 1973 r. Wynikiem tej debaty był dokument nazwany Manifestem z Davos, w którym do celów ekonomicznych każdego przedsiębiorstwa dodano również cele społeczne. Były one konsekwencją zmiany sposobu postrzegania przedsiębiorstwa w jego otoczeniu społecznym. Na każdy podmiot gospodarujący nałożono powinność służenia, spełniania oczekiwań otoczenia przedsiębiorstwa i równoważenia interesów różnych grup, które w nim funkcjonują ${ }^{9}$.

Na początku lat osiemdziesiątych XX w. Archi Carroll stworzył koncepcję określaną mianem ,społecznej efektywności korporacji”. Jej podstawowym założeniem było oparcie relacji między przedsiębiorstwami, pracownikami i otoczeniem społecznym na umowie społecznej, której fundamentami były: zasada wolności gospodarowania, a tym samym wolności przedsiębiorców do podejmowania decyzji co do zakresu podejmowanych

\footnotetext{
${ }^{8}$ A. Laska, Społeczna odpowiedzialność biznesu a konkurencyjność przedsiębiorstw w Unii Europejskiej, „Zeszyty Naukowe Politechniki Rzeszowskiej” 260, ,Zarządzanie i Marketing” 16/1 (2009), s. 106.

9 J. Korpus, Spoteczna odpowiedzialność przedsiębiorstw $w$ obszarze ksztattowania środowiska pracy, Placet, Warszawa 2006, s. 61.
} 
działań, prawna zasada równości szans rynkowych oraz zasada równości szans zatrudnienia wynikająca z przesłanek etycznych.

Koniec ubiegłego i początek obecnego stulecia wraz z intensyfikacją zmian społecznogospodarczych doprowadził do podjęcia prób sprecyzowania definicji i zasad funkcjonowania społecznej odpowiedzialności biznesu. W 2001 r. w dokumencie Komisji Europejskiej Green Paper. Promoting a European framework for Corporate Social Responsibility stwierdzono, że społeczna odpowiedzialność biznesu to „koncepcja, zgodnie z którą przedsiębiorstwa dobrowolnie uwzględniają względy społeczne i ekologiczne w codziennej działalności operacyjnej $i \quad w$ swoich kontaktach $z$ interesariuszami”. W dokumencie tym omówiono również zasady odpowiedzialności biznesu oraz sposoby jej wdrażania na poziomie europejskim.

Różnorodność podejść i rozumienia koncepcji społecznej odpowiedzialności biznesu znalazła odzwierciedlenie w sferze definicyjnej. Wskazuje się na pewne prawidłowości i mechanizmy funkcjonowania przedsiębiorstwa wobec otoczenia zewnętrznego, na przykład stwierdzając, że społeczna odpowiedzialność biznesu zaczyna się tam, gdzie kończy się oddziaływanie norm prawa. Zatem można przyjać, że społeczna odpowiedzialność biznesu to akceptacja przez przedsiębiorstwo społecznego zobowiązania poza wymaganiami prawa.

W literaturze wskazuje się cztery podstawowe poziomy społecznej odpowiedzialności biznesu:

1. odpowiedzialność ekonomiczna (maksymalizacja zysku, doskonalenie efektywności, ciągły rozwój);

2. odpowiedzialność prawna (bezwzględne przestrzeganie przepisów prawa, norm warunkujących produkcję bezpiecznych wyrobów, przestrzeganie postanowień „umowy społecznej" zarówno w wymiarze wewnętrznym, jak i zewnętrznym funkcjonowania przedsiębiorstwa);

3. odpowiedzialność etyczna (przestrzeganie obowiązujących w danym społeczeństwie, czy kręgu kulturowym norm, obyczajów, zwyczajów społecznych, norm moralnych);

4. odpowiedzialność filantropijna (sponsoring i działalność dobroczynna, np. w dziedzinie sztuki, edukacji, społeczności lokalnej).

Współcześnie przedsiębiorstwa $\mathrm{w}$ aspekcie społecznej odpowiedzialności biznesu mogą korzystać z dwóch standardów, umożliwiających prowadzenie procedur w sposób kontrolowany. Popularnym standardem odpowiedzialności jest AA1000 ${ }^{10}$, który stanowi narzędzie ułatwiające określenie celów strategicznych, mierzenie postępów w osiąganiu tych celów oraz przeprowadzenie audytu organizacji. Drugim spośród standardów jest

\footnotetext{
10 AccountAblility 1000 (AA1000) - standard zapewniający systematyczne, wszechstronne i wiarygodne podnoszenie jakości społecznej i etycznej obliczalności (accountability) organizacji, a także innych aspektów jej działania. Ramy standardu AA1000 zostały opracowane przez organizację AccountAblility pochodzącą z Wielkiej Brytanii. Miał on odpowiadać na potrzeby organizacji związane $\mathrm{z}$ włączaniem procesów angażowania interesariuszy do codziennej pracy. Standard ten dostarcza użytkownikom wskazówek, jak stworzyć systematyczny proces angażowania interesariuszy, aby mógł generować wskaźniki, cele i systemy raportowania konieczne do skutecznego wpływania na decyzje, działania i ogólną pracę organizacji.
} 
SA8000 ${ }^{11}$ będący uniwersalną normą przeznaczoną do stosowania w systemie niezależnej weryfikacji, określającym wymogi w zakresie odpowiedzialności społecznej, jakie dana firma powinna spełniać przede wszystkim w aspekcie $w$ obrębie relacji z pracownikami ${ }^{12}$.

W 2010 r. Międzynarodowa Organizacja Standaryzacji opublikowała normę ISO $26000^{13}$ stanowiącą jedną z najważniejszych wykładni CSR, która:

- przyczynia się do zrównoważonego rozwoju, zdrowia i dobrobytu społeczeństwa;

- uwzględnia oczekiwania interesariuszy;

- jest zgodna z obowiązującym prawem i międzynarodowymi normami;

- jest spójna z organizacją i z praktykowanymi w niej relacjami.

Zakres oddziaływania społecznej odpowiedzialności biznesu wskazuje jednocześnie zakres odnoszonych przez przedsiębiorstwo korzyści. W literaturze najczęściej wskazuje się na trzy podstawowe obszary: zewnętrzny, wewnętrzny i społeczny. Do korzyści zewnętrznych przedsiębiorstwa zalicza się:

- wzrost zainteresowania inwestorów;

- $\quad$ zwiększenie lojalności konsumentów i interesariuszy;

- budowanie pozytywnego wizerunku firmy;

- uwiarygodnienie misji firmy;

- $\quad$ poprawę relacji ze społecznością i władzami lokalnymi;

- $\quad$ poprawę reputacji firmy;

- $\quad$ wzrost konkurencyjności;

- obniżenie kosztów i wzrost sprzedaży.

- Wśród korzyści wewnętrznych przedsiębiorstwa można wymienić:

- wzrost efektywności firmy;

- $\quad$ ograniczenie ryzyka działalności;

- $\quad$ podnoszenie poziomu kultury organizacyjnej firmy;

\footnotetext{
11 Social Accountability 8000 (SA8000) - Bilansowanie Społeczne. Międzynarodowy standard bilansowania społecznego jest inicjatywą powołaną przez Social Accountability International (SAI). Celem SA8000 jest zapewnienie etycznych fundamentów oferowanych usług i towarów. SA8000 to dobrowolny standard, który może być stosowany w organizacjach różnej wielkości i w stosunku do przedsiębiorstw $\mathrm{z}$ dowolnej branży. Może zastapić lub uzupełnić kodeksy odpowiedzialności społecznej specyficzne dla danej spółki lub branży. SA8000 ustala podstawowe standardy regulujące kwestie: zatrudniania dzieci, stosowania pracy przymusowej, spełniania zaleceń bezpieczeństwa środowiska pracy, wolności zrzeszania się i prawa do negocjacji zbiorowych, stosowania dyskryminacji, przymusu fizycznego lub psychicznego, przestrzegania dopuszczalnej liczby godzin pracy, systemów wynagradzania i zarządzania.

${ }^{12}$ B. Rok, Odpowiedzialny biznes w nieodpowiedzialnym świecie, Akademia Rozwoju Filantropii w Polsce. Forum Odpowiedzialnego Biznesu, Warszawa 2004, s. 40.

${ }^{13}$ ISO 26000 Guidance on social responsibility - norma międzynarodowa dotycząca społecznej odpowiedzialności. Norma nie podlega certyfikacji. ISO 26000 stanowi przewodnik po ideach odpowiedzialnego biznesu. Definiuje CSR jako: „Odpowiedzialność organizacji za wpływ jej decyzji i działań (produkty, serwis, procesy) na społeczeństwo i środowisko, poprzez przejrzyste i etyczne zachowanie".
} 
- kształtowanie pozytywnego wizerunku firmy wśród pracowników;

- pozyskanie i utrzymanie najlepszych pracowników;

- zwiększenie poczucia identyfikacji pracowników z firmą.

- Natomiast korzyści społeczne to:

- nagłośnienie i rozwiązywanie istotnych problemów społecznych;

- edukowanie społeczeństwa;

- poprawa stanu środowiska naturalnego;

- dostęp do informacji o firmie;

- poszanowanie praw człowieka.

Każdy z tych obszarów ma swoją specyfikę. Korzyści zewnętrzne oddziałują na poprawę efektów gospodarowania głównie przez sferę wizerunkowo-reputacyjną przedsiębiorstwa. Uzasadnia to wzrastający udział $\mathrm{w}$ zarządzaniu przedsiębiorstwem służb public relations. Obszar korzyści wewnętrznych odnosi się głównie do dziedziny zarządzania zasobami ludzkimi, a w szerszym kontekście - do funkcjonującej w przedsiębiorstwie kultury organizacyjnej. Natomiast obszar korzyści społecznych dotyczy głównie istotnych problemów i kwestii szeroko pojętego społeczeństwa ${ }^{14}$.

\section{WPLYW LOGISTYKI NA ŚRODOWISKO PRZYRODNICZE I SPOŁECZNE}

Logistyka to proces planowania, realizowania i kontrolowania sprawnego i efektywnego ekonomicznie przepływu surowców, materiałów, wyrobów gotowych oraz odpowiedniej informacji $\mathrm{z}$ punktu pochodzenia do punktu konsumpcji $\mathrm{w}$ celu zaspokojenia wymagan klienta ${ }^{15}$. Procesy logistyczne są jednymi z pierwszych, w których rozpoczęto poszukiwania rozwiązań proekologicznych. Potrzeba realizacji procesów logistycznych z uwzględnieniem skutków oddziaływania na środowisko naturalne oraz społeczeństwo została określona mianem logistics social responsibility ${ }^{16}$. Dotychczasowe działania w ramach LSR koncentrowały się na: logistyce zwrotnej, proekologicznym zarządzaniu łańcuchem dostaw, warunkach pracy, bezpieczeństwie transportu i magazynowania czy etycznych zachowaniach wobec kontrahentów. W 2008 r. praktycy i teoretycy logistyczni w ramach raportu The Future Supply Chain $2016^{17}$ określili podstawowe zadania, przed którymi stoi obsługa logistyczna współczesnych łańcuchów dostaw. Do najważniejszych zaliczono konieczność tworzenia transparentnych łańcuchów dostaw, w których produkt musi być produkowany, dostarczany, zużywany oraz utylizowany w sposób gwarantujący redukcję emisji $\mathrm{CO}_{2}$, zmniejszenie zużycia energii, lepsze planowanie popytu i zmniejszenie kosztów całego procesu, a także dodatkowo musi gwarantować rozwój działań w zakresie logistyki zwrotnej (reusing, recycling) również przez proekologiczne pakowanie i magazynowanie ${ }^{18}$.

\footnotetext{
${ }^{14}$ A. Laska, op. cit., s. 106-107.

15 J.J. Coyle, E.J. Bardi Jr, J.C. Langrey, Zarzqdzanie logistyczne, Polskie Wydawnictwo Ekonomiczne, Warszawa 2002, s. 51-52.

${ }^{16}$ C.R. Carter, M.M. Jennings, Logistics Social Responsibility: An Integrative Framework, „Journal of Business Logistics" 23/1 (2002), s. 12.

${ }^{17}$ The Future Supply Chain 2016. Serving Consumers in a Sustainable Way, report by GCI and Capgemini.

${ }^{18}$ G. Karwacka, op. cit., s. 2-3.
} 
Działalność w obszarze logistyki jest związana z wieloma niekorzystnymi skutkami dla szeroko rozumianego otoczenia. Do głównych szkodliwych czynników należy zaliczyć zanieczyszczanie powietrza, generowanie hałasu, wytwarzanie odpadów, powodowanie wypadków i przyczynianie się do globalnego ocieplenia. Transport ładunków w skali samej Unii Europejskiej jest źródłem niemal 54\% całkowitej emisji tlenków azotu, 45\% tlenku węgla, 23\% niemetanowych lotnych związków organicznych. Odpowiada również za ponad $41 \%$ emisji prekursorów ozonu troposferycznego oraz $23 \%$ emisji $\mathrm{CO}_{2}$ i niemal $20 \%$ innych gazów cieplarnianych ${ }^{19}$.

Społeczne skutki działalności firm logistycznych mogą się przejawiać w trzech głównych obszarach, a mianowicie - w obszarze produkcji, transportu i magazynowania. Skutki społeczne obejmujące obszar produkcji mogą dotyczyć wszystkich patologii zarządzania tym obszarem. Można tu wskazać następujące przykłady: dyskryminująca polityka zatrudnienia, współpraca $\mathrm{z}$ dostawcami wykorzystującymi pracowników, oferowanie niskiej płacy i praca w zagrażającym, ryzykownym środowisku. Społeczne skutki działalności transportu mogą obejmować na przykład wydłużanie czasu pracy, niskie wynagrodzenia, koszty społeczne wypadków. Społeczne skutki magazynowania mogą przybrać formę dyskryminowania pracowników, pozbawienia ich szkoleń, niezapewnienia niezbędnego sprzętu dla pracowników itp.

Koszty te muszą być likwidowane lub minimalizowane w obliczu wzrastającej roli branży logistycznej w gospodarce światowej oraz wzrastającej presji uczestnictwa w rozwiązywaniu problemów społecznych i środowiskowych. Jednocześnie firmy logistyczne powinny dostrzegać, że stosowanie zasad zrównoważonego rozwoju może się przyczynić do ${ }^{20}$ :

- utrzymania klientów, którzy zajmują się kwestiami społecznymi i środowiskowymi;

- uzyskania przewagi konkurencyjnej dzięki innowacyjności produktów;

- przyciagnięcia i zatrzymania wykwalifikowanych pracowników, którzy troszczą się o zrównoważony rozwój;

- zwiększenia wydajności przez zmniejszenie zużycia energii;

- utrzymania licencji, która pozwala im działać;

- zachęcenia inwestorów do poszukiwania organizacji działających w zrównoważony sposób;

- utrzymanie dobrej reputacji i wizerunku marki przedsiębiorstwa.

Aby zrealizować takie założenia, firmy logistyczne w obszarze środowiska muszą wdrażać zasady tak zwanej zielonej logistyki, a w obszarze relacji społecznych - włączyć się w ruch społecznej odpowiedzialności biznesu.

\footnotetext{
${ }^{19}$ A.J. Badyda, Zagrożenia środowiskowe ze strony transportu, „Nauka” 2010/4, s. 115.

${ }^{20}$ Accounting for Sustainability: Practical Insights, red. A.G. Hopwood, J. Unerman, J. Fries, Earthscan, London 2010, s. 33.
} 


\section{ZIELONA LOGISTYKA}

Działania logistyczne obejmują takie obszary, jak: produkcja, dystrybucja, przechowywanie, transport i gospodarka magazynowa. W związku z tym logistyka jest ważnym elementem systemu gospodarczego, nie tylko na poziomie krajowym, ale także w szerszym kontekście globalnym. Poświadcza to fakt, że istnieją obecnie koncepcje systemów logistycznych w każdej sferze społeczeństwa i gospodarki narodowej.

W początkowym okresie rozwoju logistyki szybki rozwój technologiczny i konieczność nowych koncepcji transportu prowadziły do niezrównoważonego rozwoju. W analizach działań logistycznych pomijany był aspekt ekologiczny, gdyż nie był on kluczowym elementem świadomości społecznej. W ciągu ostatnich 20-30 lat sytuacja się zmieniła.

Pierwsze obawy dotyczące szkodliwego oddziaływania logistyki i transportu na środowisko zostały zarejestrowane w 1950 r., przy czym większość z istotnych badań poświęconych temu zagadnieniu pochodzi z połowy lat sześćdziesiątych XX w. Pierwsze prace badawcze odnoszące się bezpośrednio do zielonej logistyki pochodzą z początków lat dziewięćdziesiątych XX w. Wskazywano w nich, że już w tym okresie kwestie ochrony środowiska stały się najważniejszą siłą oddziałującą na gospodarkę. Większość kadr kierowniczych branży logistycznej było przekonanych, że lata dziewięćdziesiąte będą ,dekadą środowiska"21.

Rosnące znaczenie ekologii w zarządzaniu miało dla zarządzania logistycznego dwie konsekwencje. Pierwsza $\mathrm{z}$ nich była związana $\mathrm{z}$ rozszerzeniem zakresu logistyki o tak zwaną logistykę odwrotną, oznaczającą zmianę kierunku dystrybucji, gdzie oprócz tradycyjnego ruchu od producenta do konsumenta, pojawił się również kanał zwrotny od konsumenta do producenta, który z racji odpowiedzialności za produkt zobowiązany jest do jego utylizacji po okresie użytkowania. Działania logistyki odwrotnej można podzielić na cztery główne grupy:

1. gromadzenie;

2. badania, wybór i procesy sortowania;

3. przerób;

4. redystrybucja.

Druga z konsekwencji była związana ze zmianą sposobu funkcjonowania kadry zarządzającej w branży logistycznej. Musiała ona w planowaniu strategii firm logistycznych w coraz większym zakresie uwzględniać takie elementy, jak: gospodarowanie odpadami oraz minimalizowanie zanieczyszczenia środowiska - tym samym istniała potrzeba tworzenia zielonej logistyki.

Koncepcja zielonej logistyki obejmuje strategie i działania w zakresie operacji logistycznych, które są zaprojektowane w taki sposób, aby posiadały mniej negatywny wpływ na środowisko. Korzyści wynikające $\mathrm{z}$ zastosowania tej koncepcji w poszczególnych firmach może być wiele, a mianowicie: oszczędność energii, niższe koszty operacyjne i możliwość pozycjonowania na rynkach, na których obiekt jest zgodny z normami ochrony środowiska.

Jednocześnie szybko okazało się, że projektowanie zielonej logistyki tylko w jednym, określonym punkcie w łańcuchu dostaw nie przynosi większych korzyści. Dlatego też zielona logistyka jest zbiorem zorganizowanych działań, które składają się z: planowania

\footnotetext{
${ }^{21}$ P. Murphy, R.F. Poist, C.D. Braunschweig, Management of Environmental Issues in Logistics:
} current status and future potential, ,,Transportation Journal” 34/1 (1994), s. 48-56. 
produkcji ekologicznej, ekologicznego transportu, zmniejszania ilości odpadów, oszczędności energii, oszczędności miejsca, oszczędności zasobów, planowania zielonego zarządzania łańcuchem dostaw i posiadania ,zielonego” konsumenta.

Badania wykazały również, że przepisy i monitorowanie norm przedsiębiorstw logistycznych nie wystarczą i że przedsiębiorstwa w ramach łańcucha dostaw potrzebują narzędzi, które poprowadzą je przez identyfikację ekologicznie wrażliwych punktów i zaproponują wdrożenie ekologicznych koncepcji do istniejących systemów logistycznych ${ }^{22}$.

Odpowiedzią na zapotrzebowanie firm, konsumentów, a także środowisk rządowych było stworzenie systemu norm ISO 14000 . Wdrożenie podejścia opartego na tym systemie zarządzania pomaga firmom skupić uwagę na kwestiach ochrony środowiska i dostosowania ich do głównego nurtu procesu decyzyjnego w korporacji. ISO 14000 pomaga zintegrować systemy zarządzania środowiskowego firm, które handlują ze sobą zarówno w wymiarze lokalnym, jak i globalnym. W procesy ISO nie są w pełni zaangażowane wszystkie kraje lub poziomy działalności. Jednocześnie ważne jest to, że w normy ISO 14000 wpisane są zasady zrównoważonego rozwoju. Korzyści dla firm logistycznych z wdrożenia ISO 14000 mogą być wieloaspektowe. Można do nich zaliczyć: minimalizowanie negatywnego oddziaływania firm na środowisko, właściwy wizerunek marketingowy, zyski otrzymywane z działań oszczędnościowych (energia, zasoby, miejsce) itp. Można mówić również o obniżaniu kosztów dzięki nawiązaniu współpracy z innymi „,zielonymi” firmami, co zapewnia określony poziom jakości towarów i usług.

Kolejnym obszarem oddziałującym na branżę logistyczną są instytucje Unii Europejskiej. Współcześnie przejawia się to opracowaniem europejskiego modelu zrównoważonej logistyki. Pojęcie to obejmuje trzy główne obszary: społeczeństwo, gospodarkę i środowisko, w różnych aspektach ich funkcjonowania, a mianowicie:

1. społeczeństwo: bezpieczeństwo, zdrowie, sprawiedliwość;

2. gospodarka: zatrudnienie, konkurencyjność, efektywność, dynamika, wybór;

3. środowisko: zmiany jakości powietrza, hałasu, użytkowania gruntów, różnorodność biologiczna, odpady i klimat.

Jednocześnie należy zauważyć, że ,zrównoważona logistyka” to przede wszystkim inicjatywy i działania wynikające z powszechnego rozumienia potrzeby uwzględniania przy określaniu własnych celów biznesowych konieczności racjonalnego gospodarowania zasobami naturalnymi, a także dostrzegania potrzeb i uwarunkowań społecznych (w tym szeroko rozumianego bezpieczeństwa) jako kluczowych priorytetów. Zrównoważona logistyka to nie tylko spełnienie oczekiwań i wymagań nakładanych na przykład przez regulacje Unii Europejskiej, ale przede wszystkim to naturalny kierunek rozwoju każdego przedsiębiorstwa, które chce konkurować na rynku lokalnym czy światowym w sposób odpowiedzialny i perspektywiczny ${ }^{23}$.

\footnotetext{
${ }_{22}$ M. Złoch, J. Kaliński, Logistycy sq odpowiedzialni. Raport - Społeczna odpowiedzialność biznesu, „Logistyka a Jakość” marzec-kwiecień 2011, s. 18-23.

23 Zrównoważona logistyka kierunkiem rozwoju, http://www.logistyczny.com.pl (dostęp: 15.09.2014).
} 


\section{SPOŁECZNA ODPOWIEDZIALNOŚĆ BIZNESU W LOGISTYCE}

Logistyka i transport mogą odgrywać bardzo pozytywną rolę w rozwoju gospodarczym społeczeństwa, mogą wręcz stanowić podstawę dla rozwoju na poziomie lokalnym, jak i globalnym, a także przyczyniać się do rozwoju dobra społecznego, zarówno w obszarze stabilnego wzrostu gospodarczego, jak i sytuacji nagłych, na przykład przez dostarczanie pomocy w sytuacji katastrofy humanitarnej. Jednocześnie wzrasta presja zarówno społeczna, jak i klientów oraz innych grup interesariuszy na społeczne zaangażowanie firm logistycznych, co ma zapewnić korzyści w postaci etycznego postępowania i uwzględniania interesów społecznych.

Uzasadnienie dla zaangażowania CSR w branży logistycznej wydaje się oczywiste. Po pierwsze wynika ono z szerokiego kontekstu gospodarczego. Współczesna gospodarka ma charakter globalny pod każdym względem, a przedsiębiorstwa, aby mogły się rozwijać, muszą być aktywne w prowadzeniu działalności gospodarczej wśród grup dostawców i klientów na świecie. Jednocześnie sektor logistyki jest bardzo ważny na poziomie rynków krajowych, dla których ma fundamentalne znaczenie w wymiarze ich rozwoju gospodarczego, powiązań handlowych i rozwoju przedsiębiorstw. Po drugie logistyka zajmuje strategiczną pozycję między innymi sektorami, co daje jej możliwość kontaktu z ogromną różnorodnością przedsiębiorstw i sektorów przemysłu, a to pozwala na czerpanie wzorów i zawiązywanie współpracy w obszarze CSR. Po trzecie firmy logistyczne znajdują się pod ciagłą presją klientów i społeczeństwa, aby odpowiedzialność społeczna była trwałym składnikiem ich strategii, co wydaje się uzasadnione, biorąc pod uwagę silną konkurencję na rynku, wymuszającą ciągłe poszukiwanie czynnika przewagi konkurencyjnej.

Firmy logistyczne mają kilka kluczowych grup interesariuszy, a mianowicie:

- pracowników - kierowcy ciężarówek, kierowcy, pracownicy magazynowi, personel przeładunkowy, personel dostawczy i obsługi klienta, kadra zarządzająca;

- administrację państwową - lokalne, krajowe i międzynarodowe organy regulacyjne;

- klientów - korporacyjni, indywidualni, rząd;

- inwestorów - indywidualnych, instytucjonalnych, inwestorów bazujących na wartościach etycznych i społecznych, Społecznie Odpowiedzialne Inwestowanie (SRI, socially responsible investment);

- dostawców - sektor motoryzacyjny, przemysł celulozowo-papierniczy, sektor energetyczny, linie lotnicze i morskie itd.;

- partnerów joint venture - małe i średnie przedsiębiorstwa (MŚP), koncerny międzynarodowe;

- agencje i fundacje pomocowe;

- społeczności - w okolicy lokalizacji baz, portów i szlaków transportowych, społeczności lokalne. 
Z doświadczeń firm logistycznych wynika, że formy działań w zakresie CSR są bardzo różnorodne ${ }^{24}$, w tym:

- opracowanie strategii w zakresie CSR i raportów społecznych (np. British Airways);

- zaangażowanie pracowników w działalność społeczności na poziomie lokalnym (np. DHL);

- pomoc dla małych firm i organizacji społeczeństwa obywatelskiego w zakresie kształcenia, usług klientów, logistyki i marketingu;

- globalna pomoc logistyczna projektów (np. Exel i Partnerstwo cyfrowe);

- katastrofy (np. działalność DHL w Ameryce Środkowej po przejściu huraganu);

- konflikt związany z przebudową łańcucha dostaw (np. DHL w Kosowie).

Możliwości zaangażowania społecznej odpowiedzialności biznesu w branży logistycznej przedstawiono w tabeli 1 .

Tabela 1. Możliwości zaangażowania społecznej odpowiedzialności biznesu (CSR, corporate social responsibility) w branży logistycznej

\begin{tabular}{|c|c|c|c|}
\hline $\begin{array}{l}\text { Obszary } \\
\text { CSR }\end{array}$ & $\begin{array}{c}\text { Znaczenie } \\
\text { dla sektora logistyki }\end{array}$ & $\begin{array}{r}\text { Kluczowi } \\
\text { interesariusze }\end{array}$ & $\begin{array}{c}\text { Możliwe działania } \\
\text { z zakresu CSR }\end{array}$ \\
\hline Reputacja & \begin{tabular}{|l|} 
Niektóre usługi kurierskie mogą \\
być bardzo widoczne w niektórych \\
krajach i społecznościach \\
lokalnych, z racji dużej \\
częstotliwości dostaw do klientów \\
w sektorze publicznym i \\
prywatnym. Umożliwia to również \\
postrzeganie tych firm jako \\
dbających o przestrzeganie \\
wysokich standardów
\end{tabular} & $\begin{array}{l}\text { Kierowcy } \\
\text { ciężarówek, } \\
\text { kierowcy, } \\
\text { społeczności } \\
\text { lokalne, } \\
\text { partnerzy joint } \\
\text { venture }\end{array}$ & $\begin{array}{l}\text { Corporate community może być } \\
\text { skutecznym narzędziem } \\
\text { pozwalającym na ukształtowanie } \\
\text { wizerunku firmy mającej pozytywny } \\
\text { wpływ na społecznośc. Firmy } \\
\text { logistyczne z dobrą reputacją w } \\
\text { zakresie CSR mogą się stać } \\
\text { partnerem z wyboru we współpracy } \\
\text { biznesowej z innymi firmami, które } \\
\text { same są zaangażowane w CSR }\end{array}$ \\
\hline $\begin{array}{l}\text { Wartości } \\
\text { korporacyjne }\end{array}$ & $\begin{array}{l}\text { Działalność na rynku globalnym } \\
\text { może być bardzo ryzykowna z } \\
\text { punktu widzenia kosztów, } \\
\text { spełniania oczekiwań klientów, } \\
\text { terminów dostaw i zgodności z } \\
\text { przepisami, bez dobrze } \\
\text { zorganizowanego i } \\
\text { zintegrowanego zarządzania } \\
\text { łańcuchem dostaw }\end{array}$ & $\begin{array}{l}\text { Agencje } \\
\text { rządowe, klienci }\end{array}$ & $\begin{array}{l}\text { Firmy mogą stosować } \\
\text { międzynarodowe standardy w } \\
\text { obszarach, w których krajowe ramy } \\
\text { prawne mogą nie być opracowane, } \\
\text { lub współpracować z właściwymi } \\
\text { instytucjami rządowymi w celu } \\
\text { opracowania takich standardów. } \\
\text { Wiele przedsiębiorstw na podstawie } \\
\text { swoich wartości podejmuje } \\
\text { zobowiązania do etycznego } \\
\text { postępowania, muszą być one }\end{array}$ \\
\hline
\end{tabular}

\footnotetext{
${ }^{24}$ Do najpowszechniej stosowanych narzędzi realizacji odpowiedzialnego biznesu należą: kampanie społeczne - działania ukierunkowane na zmianę postaw lub zachowań wybranej grupy odniesienia pomocy mediów jako nośnika przekazu; marketing zaangażowany społecznie (cause related marketing) - uwzględnianie w działalności firmy celów marketingowych oraz potrzeb społecznych; programy etyczne dla pracowników - przedsięwzięcie mające na celu integrowanie pracowników firmy wokół wspólnych wartości.
} 


\begin{tabular}{|c|c|c|c|}
\hline $\begin{array}{c}\text { Obszary } \\
\text { CSR }\end{array}$ & $\begin{array}{c}\text { Znaczenie } \\
\text { dla sektora logistyki }\end{array}$ & $\begin{array}{r}\text { Kluczowi } \\
\text { interesariusze }\end{array}$ & $\begin{array}{c}\text { Możliwe działania } \\
\text { z zakresu CSR }\end{array}$ \\
\hline & & & $\begin{array}{l}\text { jednak poparte silnym } \\
\text { przywództwem w zarządzaniu } \\
\text { strukturami }\end{array}$ \\
\hline Korupcja & $\begin{array}{l}\text { Częsty ruch transgraniczny naraża } \\
\text { sektor towarowy i transport na } \\
\text { nadużycia, przemyt lub w } \\
\text { skrajnych wypadkach - na } \\
\text { terroryzm }\end{array}$ & $\begin{array}{l}\text { Społeczności } \\
\text { lokalne, } \\
\text { partnerzy joint } \\
\text { venture, rządy }\end{array}$ & $\begin{array}{l}\text { Oparcie się w swej działalności na } \\
\text { rygorystycznie przestrzeganym } \\
\text { kodeksie postępowania w biznesie } \\
\text { może skutecznie zniechęcić do } \\
\text { nielegalnej działalności tego typu } \\
\text { interesariuszy. Jeżeli firma } \\
\text { logistyczna odmówi współpracy z } \\
\text { klientami, którzy nie opierają } \\
\text { swoich praktyk biznesowych na } \\
\text { podobnych normach postępowania, } \\
\text { firmy nastawione na łamanie } \\
\text { przepisów utracą możliwość } \\
\text { działania. Niezbędna okazuje się } \\
\text { również ścisła współpraca ze } \\
\text { służbami zapewniającymi w tym } \\
\text { zakresie ład i bezpieczeństwo }\end{array}$ \\
\hline $\begin{array}{l}\text { Zapobieganie i } \\
\text { rozwiązywanie } \\
\text { konfliktów }\end{array}$ & $\begin{array}{l}\text { W obecnej sytuacji } \\
\text { międzynarodowej występują } \\
\text { zagrożenia terrorystyczne (np. } \\
\text { rozsyłanie wąglika czy skażenia } \\
\text { produktów żywnościowych) }\end{array}$ & Rząd & $\begin{array}{l}\text { Firmy logistyczne mogą } \\
\text { współpracować z rządami i innymi } \\
\text { instytucjami w znalezieniu sposobu } \\
\text { minimalizacji tego ryzyka }\end{array}$ \\
\hline $\begin{array}{l}\text { Łagodzenie } \\
\text { konsekwencji } \\
\text { katastrof }\end{array}$ & $\begin{array}{l}\text { W wyniku klęsk żywiołowych, } \\
\text { takich jak trzesienia ziemi, } \\
\text { wybuchy wulkanów, powodzie } \\
\text { itp., konieczna jest często znaczna } \\
\text { pomoc humanitarna, która musi } \\
\text { dotrzeć do określonych miejsc. } \\
\text { Nawet stosunkowo niewielkie } \\
\text { wydarzenie, jak zburzony most z } \\
\text { powodu powodzi, może mieć } \\
\text { wpływ na sektor logistyczny }\end{array}$ & $\begin{array}{l}\text { Agencje } \\
\text { pomocowe i } \\
\text { charytatywne, } \\
\text { rządy }\end{array}$ & $\begin{array}{l}\text { Firmy logistyczne mają } \\
\text { umiejętności i doświadczenie, aby } \\
\text { szybko i skutecznie reagować w } \\
\text { przypadku klęsk żywiołowych przez } \\
\text { zapewnienie koordynacji i transport } \\
\text { pomocy, materiałów budowlanych, } \\
\text { żywności, zapewnienie } \\
\text { tymczasowych schronów, } \\
\text { wynajdywanie nowych dróg itp. } \\
\text { Firmy logistyczne nie tylko mogą } \\
\text { pomóc z racji posiadania doskonałej } \\
\text { znajomości warunków lokalnych, } \\
\text { ale również mogą osiagnąć korzyści } \\
\text { w obszarze reputacji społecznej, co } \\
\text { z kolei może znaleźć przełożenie na } \\
\text { dostęp do nowej bazy klientów i } \\
\text { generowanie nowych kanałów } \\
\text { dystrybucji. W niektórych } \\
\text { wypadkach brak aktywności może } \\
\text { mieć negatywny wpływ na } \\
\text { działalność, jeśli komunikacja i } \\
\text { kanały dystrybucji są uszkodzone }\end{array}$ \\
\hline $\begin{array}{l}\text { Lokalne } \\
\text { społeczności }\end{array}$ & $\begin{array}{l}\text { Budowanie portów, dróg i } \\
\text { autostrad, linii kolejowych i } \\
\text { lotnisk może się wiązać ze } \\
\text { znacznym oporem społeczności } \\
\text { lokalnych }\end{array}$ & $\begin{array}{l}\text { Społeczności } \\
\text { lokalne, rząd }\end{array}$ & $\begin{array}{l}\text { Firmy logistyczne dobrze znające } \\
\text { społeczności lokalne i istniejące } \\
\text { szlaków transportowe mogą być } \\
\text { użyteczne dla firm budowlanych w } \\
\text { procesie planowania nowych, } \\
\text { znaczących zmian } \\
\text { drogowych/kolejowych/lotniczych. } \\
\text { Mogą również pomóc } \\
\text { społecznościom leżącym poza } \\
\text { głównymi szlakami }\end{array}$ \\
\hline
\end{tabular}




\begin{tabular}{|c|c|c|c|}
\hline $\begin{array}{l}\text { Obszary } \\
\text { CSR }\end{array}$ & $\begin{array}{c}\text { Znaczenie } \\
\text { dla sektora logistyki }\end{array}$ & $\begin{array}{r}\text { Kluczowi } \\
\text { interesariusze } \\
\end{array}$ & $\begin{array}{c}\text { Możliwe działania } \\
\text { z zakresu CSR }\end{array}$ \\
\hline & & & $\begin{array}{l}\text { komunikacyjnymi w dotarciu do } \\
\text { nich }\end{array}$ \\
\hline $\begin{array}{l}\text { Osoby ubiegające } \\
\text { się o azyl / } \\
\text { imigracja }\end{array}$ & $\begin{array}{l}\text { Ruchy migracyjne mogą się } \\
\text { przyczyniać do znacznych strat } \\
\text { firm logistycznych. } \\
\text { Według danych z } 2001 \text { r. firma } \\
\text { zarządzająca Eurotunelem straciła } \\
\text { ok. } 20 \text { mln funtów z powodu } \\
\text { przemieszczania się nielegalnych } \\
\text { imigrantów }\end{array}$ & \begin{tabular}{|l|} 
Agencje \\
rządowe, \\
partnerzy, \\
dostawcy joint \\
venture
\end{tabular} & $\begin{array}{l}\text { Migracja transgraniczna przynosi } \\
\text { firmom logistycznym coraz większe } \\
\text { zagrożenia w transporcie osób i } \\
\text { towarów. W obszarze tym mogą one } \\
\text { współpracować z władzami } \\
\text { państwowymi i innymi } \\
\text { zainteresowanymi stronami, w celu } \\
\text { poszukiwania korzystnych } \\
\text { rozwiązań dla obu stron }\end{array}$ \\
\hline Zdrowie & \begin{tabular}{|l|} 
Działalność logistyczna o zasięgu \\
globalnym może się przyczynić do \\
rozprzestrzeniania występujaccych \\
w środowiskach lokalnych chorób. \\
Pracownicy tych firm są \\
szczególnie narażeni na tego typu \\
zagrożenia
\end{tabular} & $\begin{array}{l}\text { Kierowcy } \\
\text { ciężarówek, } \\
\text { kierowcy, } \\
\text { społeczności } \\
\text { lokalne, władze } \\
\text { zdrowotne }\end{array}$ & $\begin{array}{l}\text { Firmy logistyczne dzięki znajomości } \\
\text { obszarów, które obejmują } \\
\text { łańcuchem dostaw, mogą się stać } \\
\text { doskonałym nośnikiem wszelkich } \\
\text { kampanii zdrowotnych }\end{array}$ \\
\hline $\begin{array}{l}\text { Rozwój } \\
\text { przedsiębiorstw }\end{array}$ & \begin{tabular}{|l|} 
Firmy logistyczne świadczace \\
usługi we wszystkich czéściach \\
świata mogą, dzięki swoim \\
umiejętnościom i zasobom, stać się \\
podstawą rozwoju obszarów do tej \\
pory wykluczonych z rywalizacji \\
ekonomicznej
\end{tabular} & \begin{tabular}{|l|} 
Pracownicy, \\
klienci \\
korporacyjni, \\
partnerzy joint \\
venture
\end{tabular} & $\begin{array}{l}\text { Umiejętności i doświadczenia, w } \\
\text { tym planowanie trasy, formy obsługi } \\
\text { klienta, mogą być przekazywane } \\
\text { między największymi } \\
\text { międzynarodowymi firmami } \\
\text { logistycznymi oraz małymi i } \\
\text { średnimi firmami lokalnymi. } \\
\text { Wzmacnia to lokalną gospodarkę } \\
\text { poprzez występujące sprzężenia } \\
\text { zwrotne w dostarczaniu cennej } \\
\text { wiedzy firmom międzynarodowym, } \\
\text { które poznają ewentualnego partnera } \\
\text { w dystrybucji }\end{array}$ \\
\hline $\begin{array}{l}\text { Wykluczenie } \\
\text { cyfrowe }\end{array}$ & \begin{tabular}{|l|} 
Duże firmy logistyczne posługują \\
się wysoko zaawansowaną \\
technologią informatyczną. \\
Poziom technologii, które \\
używaja, może się okazać \\
niedostosowany do poziomu \\
wiedzy lokalnych społeczności, w \\
których prowadzą swą działalność
\end{tabular} & $\begin{array}{l}\text { Pracownicy, } \\
\text { społeczności } \\
\text { lokalne, lokalne } \\
\text { firmy }\end{array}$ & $\begin{array}{l}\text { Stary sprzęt komputerowy, który } \\
\text { byłby poddany recyklingowi lub } \\
\text { zniszczony może zostać } \\
\text { przeniesiony do lokalnych } \\
\text { firm/organizacji na wzór modelu } \\
\text { „Partnerstwa cyfrowego” }\end{array}$ \\
\hline \begin{tabular}{|l} 
Lokalna \\
jakość \\
środowiska
\end{tabular} & \begin{tabular}{|l|} 
Wypadki komunikacyjne są istotną \\
przyczyną zgonów. Oprócz \\
tragedii ludzkiej, firmy mogą \\
stanąć w obliczu wysokich \\
roszczeń finansowych w wypadku, \\
kiedy wykazały w tym obszarze \\
niedbałość, mogą również \\
doświadczyć negatywnego \\
wpływu na reputację firmy \\
\end{tabular} & $\begin{array}{l}\text { Lokalne } \\
\text { społeczności, } \\
\text { środowiska }\end{array}$ & $\begin{array}{l}\text { Uczestnictwo firm logistycznych w } \\
\text { rządowych i społecznych akcjach } \\
\text { mających na celu obniżenie liczby } \\
\text { wypadków }\end{array}$ \\
\hline \begin{tabular}{|l} 
Bezpieczeństwo \\
produktów
\end{tabular} & $\begin{array}{l}\text { Odpowiedzialność za przewożone } \\
\text { towary, zwłaszcza te } \\
\text { niebezpieczne, i zdarzające się } \\
\text { sytuacje kryzysowe związane z } \\
\text { wyciekami substancji } \\
\text { niebezpiecznych takich jak } \\
\text { substancje chemiczne (kwasy, ługi, }\end{array}$ & $\begin{array}{l}\text { Ochrona } \\
\text { środowiska, } \\
\text { społeczności } \\
\text { lokalne }\end{array}$ & $\begin{array}{l}\text { Respektowanie przepisów } \\
\text { regulujących ten obszar, dbałość o } \\
\text { zapewnienie bezpieczeństwa } \\
\text { przewozu towarów zgodne z } \\
\text { własnymi regulaminami }\end{array}$ \\
\hline
\end{tabular}




\begin{tabular}{|l|l|l|l|}
\hline \multicolumn{1}{|c|}{$\begin{array}{c}\text { Obszary } \\
\text { CSR }\end{array}$} & \multicolumn{1}{c|}{\begin{tabular}{c}
\multicolumn{1}{c|}{$\begin{array}{c}\text { Znaczenie } \\
\text { dla sektora logistyki }\end{array}$} \\
\hline
\end{tabular}} & $\begin{array}{c}\text { Kluczowi } \\
\text { interesariusze }\end{array}$ & \multicolumn{1}{c|}{$\begin{array}{c}\text { Możliwe działania } \\
\text { z zakresu CSR }\end{array}$} \\
\hline $\begin{array}{l}\text { Bezpieczeństwo } \\
\text { pracownika }\end{array}$ & $\begin{array}{l}\text { Pracownicy firm logistycznych } \\
\text { mogą czuć presje, aby wydłużać } \\
\text { czas pracy, a nawet złamać } \\
\text { ograniczenia prędkości ze względu } \\
\text { na narzucone czasy dostaw }\end{array}$ & $\begin{array}{l}\text { Kierowcy } \\
\text { ciężarówek, } \\
\text { kierowcy }\end{array}$ & $\begin{array}{l}\text { Konieczność funkcjonowania } \\
\text { systemu sieci wsparcia dla } \\
\text { pracowników. W razie potrzeby } \\
\text { należy rozważý wprowadzenie } \\
\text { wewnętrznych kontroli czasu pracy, } \\
\text { stanu zdrowia pracowników, } \\
\text { poziomu zadowolenia z pracy }\end{array}$ \\
\hline
\end{tabular}

Źródło: opracowanie własne na podstawie: Logistics and transport companies. Expectations and opportunities at the leading edge of corporate social responsibility, http://www.commdev.org/files/1339_file_Logistics.pdf (dostęp: 15.09.2014).

Firmy logistyczne stoją zatem obecnie wobec konieczności ustosunkowania się do występujących współcześnie wyzwań związanych ze społecznymi oczekiwaniami wzięcia na siebie dużego zakresu obowiązków społecznych - zwłaszcza jeżeli chodzi o wpływ na środowisko naturalne i społeczne. W szerszym kontekście jest to pytanie o rolę zrównoważonego rozwoju w funkcjonowaniu tych organizacji.

Podjęcie działań w zakresie zrównoważonego rozwoju wymusza nieco inne spojrzenie na funkcje realizowane przez przedsiębiorstwo. Zrównoważony rozwój firmy logistycznej jest szansą na uzyskanie wartości dodanej w aspektach środowiskowych, ekonomicznych i społecznych, lecz również staje się dużym wyzwaniem.

Na poziomie organizacji wdrażanie zasad społecznej odpowiedzialności do logistyki (łańcucha dostaw) wiąże się z wieloma barierami. Do głównych barier można zaliczyć:

- brak zaangażowania naczelnego kierownictwa;

- brak świadomości konsumentów w kwestiach społecznej odpowiedzialności przedsiębiorstw;

- ograniczenia finansowe;

- brak dbałości o reputację firmy;

- brak świadomości szerszego kontekstu CSR;

- brak planowania strategicznego w obszarze CSR;

- niechęć ze strony partnerów do wdrażania społecznej odpowiedzialności;

- brak narzędzi do mierzenia korzyści z wdrożenia CSR.

Mimo istniejących ograniczeń praktyka pokazuje, że odpowiedzialne zarządzanie logistyką (łańcuchem dostaw) może przynieść realne korzyści partnerom relacji. Stąd wiele podmiotów gospodarczych decyduje się na monitorowanie procesów zachodzących we wszystkich ogniwach łańcucha dostaw. Wdrażane są także narzędzia oceny dostawców pod kątem spełniania przez nich kryteriów społecznych i środowiskowych, implementowane kodeksy etyczne i postępowania, procedury działania oraz zintegrowane programy oparte na ciagłym doskonaleniu ${ }^{25}$.

\section{ZAKOŃCZENIE}

Jak wynika z podjętej analizy, zdecydowana większość firm logistycznych pozytywnie odpowiedziała na wyzwania współczesności, podejmując liczne działania w postaci zielonej logistyki - jeżeli chodzi o środowisko naturalne (zmniejszanie emisji gazów

${ }^{25}$ A. Rudnicka, op. cit., s. 167. 
cieplarnianych, logistyka odwrotna związana z recyklingiem i utylizacją produktów po fazie użytkowania), i działania społecznej odpowiedzialności biznesu - jeżeli chodzi o relacje ze społeczeństwem.

Duże zainteresowanie firm logistycznych zrównoważonym rozwojem wynika przede wszystkim z tego, że zrównoważony rozwój jest postrzegany jako źródło innowacji, zwłaszcza organizacyjnych i technologicznych, które przekładają się na zwiększone zyski. Jednocześnie postrzeganie przedsiębiorstwa logistycznego jako „zielonej” firmy skutkuje obniżeniem kosztów działalności gospodarczej i przyczynia się do wzmocnienia atutów marketingowych i reputacyjnych.

Firmy logistyczne w swej działalności mogą korzystać z wielu metod i środków przyczyniających się do rozwiązania nieraz trudnych kwestii ekologicznych i społecznych, zarówno w wymiarze lokalnym, jak i międzynarodowym. Należy się spodziewać, że branża logistyczna nadal będzie wdrażać zasady zrównoważonego rozwoju i podejmować działania społecznie odpowiedzialne na skalę odpowiadająca roli, jaką logistyka odgrywa we współczesnych systemach gospodarowania.

\section{LITERATURA}

[1] Accounting for Sustainability: Practical Insights, red. A.G. Hopwood, J. Unerman, J. Fries, Earthscan, London 2010.

[2] Badyda A.J., Zagrożenia środowiskowe ze strony transportu, „Nauka” 2010/4.

[3] Carter C.R., Jennings M.M., Logistics Social Responsibility: An Integrative Framework, „Journal of Business Logistics” 23/1 (2002).

[4] Coyle J.J., Bardi E.J., Langrey Jr. J.C., Zarzadzanie logistyczne, Polskie Wydawnictwo Ekonomiczne, Warszawa 2002.

[5] Karwacka G., Koncepcja społecznej odpowiedzialności w logistyce, http://www.innowrota.pl/sites/default/files/images/G.Karwacka_2.pdf.

[6] Korpus J., Spoteczna odpowiedzialność przedsiębiorstw $w$ obszarze ksztattowania środowiska pracy, Placet, Warszawa 2006.

[7] Laska A., Spoteczna odpowiedzialność biznesu a konkurencyjność przedsiębiorstw $w$ Unii Europejskiej, „Zeszyty Naukowe Politechniki Rzeszowskiej” 260, „Zarządzanie i Marketing” 16/1 (2009).

[8] Logistics and transport companies. Expectations and opportunities at the leading edge of corporate social responsibility, http://www.commdev.org/files/1339_file_Logistics.pdf.

[9] Maloni M.J., Brown M.E., Corporate Social Responsibility in the Supply Chain: An Application in the Food Industry, ,Journal of Business Ethics” 2006/68.

[10]Murphy P., Poist R.F., Braunschweig C.D., Management of Environmental Issues in Logistics: current status and future potential, „Transportation Journal” 34/1 (1994).

[11]Rok B., Odpowiedzialny biznes w nieodpowiedzialnym świecie, Akademia Rozwoju Filantropii w Polsce. Forum Odpowiedzialnego Biznesu, Warszawa 2004.

[12]Rudnicka A., Odpowiedzialność spoteczna w globalnych tańcuchach dostaw na przyktadzie certyfikacji FairTrade, „Acta Universitatis Lodziensis, Folia Oeconomica" 2011/258. 
[13]The Future Supply Chain 2016. Serving Consumers in a Sustainable Way, report by GCI and Capgemini.

[14]World Business Council for Sustainable Development, Corporate Social Responsibility: Making Good Business Sense, Geneva 2000.

[15]World Business Council for Sustainable Development, Corporate Social Responsibility: Meeting Changing Expectations, Geneva 1999.

[16]Złoch M., Największe wyzwanie to ochrona środowiska, Raport Odpowiedzialność logistycznego biznesu, „Logistyka a Jakość” marzec-kwiecień 2011.

[17]Złoch M., Kaliński J., Logistycy sq odpowiedzialni. Raport - Społeczna odpowiedzialność biznesu, „Logistyka a Jakość” marzec-kwiecień 2011.

[18]Zrównoważona logistyka kierunkiem rozwoju, http://www.logistyczny.com.pl.

\section{CORPORATE SOCIAL RESPONSIBILITY OF LOGISTICS COMPANIES}

The article analyzes the role and importance of corporate social responsibility (CSR) for the modern enterprise exemplified by logistics companies. The considerations were focused on the nature and scope of corporate social responsibility and methods of implementation in logistics companies the principles of sustainable development, in particular those of green logistics and corporate social responsibility in the sphere of relations with the social environment.

CSR is a concept in which companies voluntarily decide to support efforts for better society and cleaner environment. Is also understood as a continuous commitment of business to behave ethically and to promote economic development by improving the quality of life for employees, their families, communities and the entire societies. Following its policy contributes to the achievement of sustainable global development. Business practitioners and theoreticians are looking for ways to use the principles of corporate social responsibility in logistics.

CSR commitment in the logistics industry may result from three reasons. Firstly, from the broad economic context. Modern economy is global, in every respect, and companies that can grow must be active in a business activity among groups of suppliers and customers. Secondly, logistics is a strategic position between the other sectors, what gives a huge variety of companies and industries. Thirdly, logistics companies are under constant pressure from customers and society as the social responsibility should a permanent component of their strategy, which seems reasonable taking into account high competition in the market.

Practice shows that socially responsible logistics lies in the implementation of tools to assess suppliers in terms of meeting social and environmental criteria, implementation of codes of ethics and conduct, operating procedures and integrated programs based on continuous improvement.

Keywords: corporate social responsibility, logistics companies, socially responsible logistics, sustainable development, green logistics.

DOI:10.7862/rz.2014.hss.58

Przesłano do redakcji: październik 2014

Przyjęto do druku: grudzień 2014 